Arianne Struik

Gz-psycholoog Arianne Struik is directeur van het Institute for Chronically Traumatized Children (ICTC) in Scarborough (Perth, West- Australië) dat gespecialiseerd is in de behandeling van getraumatiseerde kinderen en hun families. Ze is auteur van het boek Slapende Honden? Wakker maken! Als 'flying psych' behandelt ze getraumatiseerde kinderen en volwassen in afgelegen gebieden.

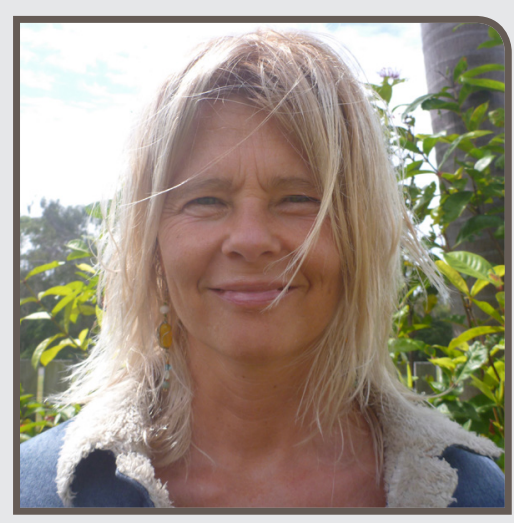

\title{
Down Under: postorderbruiden
}

Eens in de zoveel tijd komt Tony weer eens bij me binnenstappen. Sinds hij zijn zoon drie jaar geleden verloor, is hij aan lagerwal geraakt. Hij heeft een enorme bierbuik, zijn kleren zijn vies, zijn haren ongewassen en hij ruikt, maar toch heb ik een zwak voor hem. Hij worstelt nog steeds met zijn ex, zegt hij, want ze dringt zich aan hem op. Enerzijds weet hij zeker dat hij niet met haar verder wil, anderzijds is hij ook erg eenzaam na elf jaar alleen te zijn geweest.

Als we het probleem exploreren wordt hij steeds woester. Als zijn verhalen waar zijn, dan leed ze aan het Münchhausen-by-proxysyndroom (MHPS) en het hernieuwde contact met haar baart me zorgen. Nadat hij bij haar wegging, deed ze volgens hem valselijk aangifte van verkrachting. Tony zat een dag vast tot ze de aangifte introk. Slecht nieuws, deze vrouw. 'Weet je', zegt Tony, 'daarom durf ik niet met andere vrouwen af te spreken, want dat wil ik echt nooit meer mee maken; ik kan zo gemakkelijk weer van verkrachting worden beschuldigd.'
Tony ontmoet best veel vrouwen die interesse in hem tonen, maar als het dan tot een afspraak komt, haakt hij af. Ondanks dat het me niet helemaal duidelijk is hoe hij die contacten dan heeft, ben ik blij verrast want dat biedt perspectief. Een verliefdheid zou hem er wellicht toe kunnen

\section{'Ha, ha, ze}

\section{wonen in de}

\section{Oekraine!'}

bewegen om zijn kleren eens te wassen en een douche te nemen. Geduldig analyseer ik zijn dilemma en we concluderen dat de kans om opnieuw van verkrachting te worden beschuldigd voor hem vele malen groter is met zijn ex-vrouw dan met een nieuwe liefde. Niet alle vrouwen doen dat, maar van haar is zeker dat ze ertoe in staat is. Zo had hij het nog niet bekeken. Toch blijft hij hangen in de angst om het met een nieuwe vrouw te proberen. 'Hoe weet ik nu zeker dat het een goede vrouw is?' We bedenken vervolgens dat hij zijn dochter, die veel mensenkennis heeft, kan vragen naar haar mening, alvorens een stap verder te gaan. Tony wordt steeds enthousiaster en oppert om daarvoor voortaan ook de mening van zijn beste vriend te vragen. Hij mocht zijn ex al vanaf het begin van de relatie niet en heeft er volgens Tony dus ook goed kijk op.

Dan vertelt Tony dat hij op dit moment online contacten heeft met vier leuke vrouwen, hij zou niet kunnen kiezen. Als ik opper om ze alle vier uit te nodigen voor een ontmoeting, begint hij te lachten. 'Dat is een beetje lastig', zegt hij, 'want ze wonen in..' Hij noemt een plaatsnaam die ik niet kan verstaan. Hij spreekt met een sterk accent en mist een paar tanden. Ik wil niet laten merken dat ik hem niet goed verstaan heb, dus stel ik voor dat hij dan toch daarheen kan rijden met zijn vriend. Dan begint hij te lachen, 'ha, ha, ze wonen in de Oekraine!' Ik beëindig maar snel de sessie. 